\title{
Kineserne kommer
}

Det er ikke mange år siden, at man talte om 'den nye verdensorden' som betegnelse for, at USA efter den kolde krigs ophør var blevet den suverænt stærkeste magt i en multipolær verden.

I dag er der sjældent nogen, som nonchalant henviser til den nye verdensorden, og hvis de gør, er det for at slå fast, at den ikke vil vedblive at bestå.

Selv den britiske premierminister Gordon Brown - som man ellers må formode er tilhænger af en amerikansk domineret verden - ser den smuldre for øjnene af sig. Under en rundrejse i Asien i januar i år slog Brown i en tale i New Delhi til lyd for, at den nye verdensorden tager højde for det, han kaldte "det største skift i den økonomiske magtbalance i to hundrede år."

"Vi kan og skal gøre mere for at gøre vores globale institutioner repræsentative. Jeg foreslår ændringer i IMF, Verdensbanken og G8, der afspejler opkomsten af Indien og Asien", sagde Brown.

Ingen var et sekund i tvivl om, hvad han mente: Om blot få årtier vil lande som Kina, Indien, Brasilien og Mexico udgøre en større andel af verdensøkonomien end de G7-lande, som vi har været vant til at betragte som klodens kulturelle, politiske og $\varnothing$ konomiske magtcentrum. Og hvis ikke de vestlige lande allerede nu åbner de internationale institutioner for de fremvoksende stormagter og gør det muligt for dem at udøve deres indflydelse inden for den etablerede verdensorden, kan det ende med et magtskifte.

Vil Vesten erkende det i tide?

Det er et af de spørgsmål, vi søger svar på i dette nummer af Udenrigs, hvor vi har valgt at gøre Asiens største magt, Kina, til vores tema.

I nummeret vil man i det hele taget kunne læse om, hvad vi kan vente os af kineserne: Hvad vil de bruge deres magt til? Hvor hurtigt vokser den kinesiske økonomi overhovedet? Og hvordan er det lykkedes dem at opnå sådanne svimlende vækstrater?

Men det er ikke blot Kinas fremtidige påvirkning af os, der er i fokus. Vi ser også på, hvordan den voksende velstand forandrer Kina indefra: Vil den hastigt ekspanderende middelklasse kræve borgerrettigheder og demokrati for at sikre sin ejendomsret, som det i hvert fald tidligere har været antagelsen inden for samfundsvidenskaberne? Vil presset mod Kommunistpartiet komme fra de millioner af fattige, som ikke har fået del i velstandsstigningen? Eller kan man tænke sig, at autokrati og kapitalisme er en fuldt ud levedygtig samfundsmodel? God læselyst! 